\title{
IMPROVING THE ABILITY OF PROBLEM SOLVING AND INDEPENDENCE OF MATHEMATICAL VOCATIONAL SCHOOL THROUGH CONTEXTUAL APPROACHES
}

\author{
Abdul Wahab Abdullah', Asep Subhan Suryadi ${ }^{2}$ \\ 1,2 Mathematics Education Program Post Graduate IKIP Siliwangi, Cimahi \\ 1abdulwahabdeden@gmail.com, ${ }^{2}$ asepsubhan07@gmail.com ${ }^{2}$
}

Received: Jul 7 ${ }^{\text {th }}$, 2019; Accepted: Jul 19 ${ }^{\text {th }}, 2019$

\begin{abstract}
Abstrak
The background of this research is to know the needs of learning approach to deal with the ability of student in vocational high school to solve problems and their mathematic independent. The alternative approach applied is contextual approach. This research purpose is to find out the achievement and the increase of their ability in solving problems and their mathematic independent. Research methodology used in this research is experiment method. In the beginning and in the end of learning both of the class given test and non-test. Population of this research is vocational students which has intermediate skill in Bandung Barat residence, sample taken from two class randomly, the sample is X TKJ 2 as experiment class and X TKJ 3 class as control class. Instrument of the research is a test consist of 8 essay questions and 30 non-test questions. The solving problems ability and math independent then analyze using average differential test. The result of the research shows that the achievement and the ability of solving problems and math independent increasing using contextual approach than conventional approach
\end{abstract}

Keywords: Problem Solving, Contextual Approach, Independence.

\begin{abstract}
Abstrak
Penelitian ini dilatar belakangi oleh masih rendahnya kemampuan pemecahan masalah dan kemandirian matematik siswa Sekolah Menengah Kejuruan, sehingga diperlukan pendekatan pembelajaran untuk mengatasi masalah tersebut. Alternatif pendekatan yang diterapkan yaitu pendekatan kontekstual. Penelitian ini bertujuan untuk menelaah pencapaian dan peningkatan kemampuan pemecahan masalah dan kemandirian matematik siswa yang pembelajarannya menggunakan pendekatan kontekstual lebih baik daripada pembelajaran biasa serta menelaah implementasi langkah-langkah pendekatan yang diterapkan serta kesulitan-kesulitan siswa mengerjakan soal. Metode penelitian yang digunakan adalah metode eksperimen. Pada awal dan akhir pembelajaran kedua kelas diberi tes dan non tes. Populasi dalam peneitian Ini adalah siswa SMK yang berkemampuan sedang di Kapubaten Bandung Barat, sedangkan sampelnya terdiri dari dua kelas yang dipilih secara acak kelas, diperoleh kelas X TKJ 2 sebagai kelas eksperimen dan kelas X TKJ 3 sebagai kelas kontrol. Instrumen dalam penelitian ini adalah berupa tes sebanyak 8 butir soal uraian dan non tes 30 soal, kemudian data skor kemampuan pemecahan masalah dan kemandirian matematik tersebut dianalisis menggunakan uji perbedaan rata-rata. Berdasarkan hasil penelitian, penulis menyimpulkan bahwa pencapaian dan peningkatkan kemampuan pemecahan masalah dan kemandirian matematik siswa yang pembelajarannya menggunakan pendekatan kontekstual lebih baik daripada yang menggunakan pembelajaran biasa
\end{abstract}

Kata Kunci: pemecahan masalah, pendekatan kontekstual, kemandirian

How to Cite: Abdullah, Abdul Wahab \& Suryadi, Asep Subhan. (2019). Improving The Ability of Problem Solving and Independence of Mathematical Vocation School Through 
82 Fadhillah., Mahmudah, \& Kuriawan. Improving The Ability of Problem Solving and Independence of Mathematical Vocation School Through Contextual Approaches

Contextual Approaches. JIML, 2 (2), 82-87.

\section{INTRODUCTION}

Math solving problems is a step we must do in solving a problems faced (Sariningsih \& Purwasih, 2017). Solving problem skill is important in math solving problems, whether in 2006 curriculum or 2013 curriculum (Marlissa \& Widjajanti, 2015; Sariningsih \& Purwasih, 2017; Wirdaningsih, Arnawa, \& Anhar, 2015). Problems is one of important part of math curriculum, the students has a chance to get an experience using knowledge and skill they have to solve the problem (Marlissa \& Widjajanti, 2015; Wirdaningsih et al., 2015). Solving problem skill needed to achieve the purpose of 2013 curriculum (Putri \& Eliarti, 2017). Stated that the solving problem skill is one of math skill which can be define as higher thinking level. Problem solving also is a core of math. Solving problems is very important for the students to make them able to unusual questions or what have they learn before in their teaching-learning process. Solving problem is the most difficult in math for students to learn. Students able to understand math only in basic solving problem, they cannot solve the complex and complicated problems. The importance of solving problems can be felt not only for who studies mathematics, however it is also possible for those who will implement it in other fields of study in life daily (Hajar \& Sari, 2018).

The essential of math solving problem for students to find a solution of a problems in math, the teacher has an important role in making math easier to understand, in class teachinglearning process teacher act as a director and students as an actor. From their daily math test of SMK BIB class X consist of 32 students, 22 students having difficulty in solving problems, and the rest of the student able to solve their questions. Which is $28 \%$.

Math solving problem become a main focus in math learning, so the student needs to be facilitated in their learning so their skill could be better (Krismiati, 2013). The innovative learning must be applied in math learning in contextual approach. Contextual approach is one of learning alternative that could create the situation and condition in the class and mostly the students play the most part in learning. When the students able to construct himself so the students will be able to control himself in his learning, metacognition, motivation and active behavior. To solve problem they need ability to construct student knowledge. When the student get problem when the student need to solve problem. With the contextual learning, the students could learn naturally, in this approach learning process is more important than contextual approach, so that approach could increase the understand and math solving problem also their math independent (Sariningsih, 2014). Math independent is an active process in construct and set learning goal as well as to monitor, to control and motivate the students in social context. The learning done by the teacher make the students not independent. The students need to hear the explanation of the teacher, learn how to solve the problem and do the task given by the teacher (Haji \& Abdullah, 2015). Independent learning as active process in constructing and set learning goal and monitoring, Infinity Scientific journal Math Program STKIP Siliwangi Bandung, Vol 4, No.1, February 201540 Cognition control, motivation in society context. The learning done by teacher make the students not independent. The student learn by hear lecturing of the teacher, follow the step how to answer the question, and done the task given by the teacher (Sugandi, 2013). One of effective strategy in creating active learning and fun learning is to involve the student in connecting the learning material and the real world. For example in using contextual approach.

\section{METHOD}


The research method used is experiment method, there we manipulation on research object, which is the class using contextual and the other one is conventional, whereas in the beginning and the end of learning both of the class given test. The research design stated by (Ruseffendi, 2010) as follow :
A $\quad \mathrm{O} \quad \mathrm{X} \quad \mathrm{O}$
A $\mathrm{O} \quad \mathrm{O}$

A : Random sample

$\mathrm{O}:$ Pre-test $=$ Post-Test

$\mathrm{X}$ : Class with Contextual Approach

Population in this research is all of the students in Bina Insan Bangsa Ngamprah vocational high school. With sample subject is two X Classs, the sample taken randomly where the experiment class given the contextual approach and control class given the conventional approach. X TKJ 2 as experiment class and X TKJ 3 as control class.

To measure the achievement of solving problem post-test is used. To measure the math creativity skill normalized n-gain formulized by Hake (Sariningsih \& Purwasih, 2017).

$$
\text { normalized } \mathrm{N}-\text { gain }=\frac{\text { posttest score }- \text { pretest core }}{\text { Ideal score }- \text { pretest score }}
$$

Solving problem question examples:

1. Asnawari stand in the cliff above $8 \mathrm{~m}$ from the ground, he threw the ball with $40 \mathrm{~m} / \mathrm{s}$ speed (let's say the ball is off at $1 \mathrm{~m}$ from the cliff where Asnawari stand). (a) how high the ball in 2 second!, and (b) the time needed for the ball to touch the ground!

2. Ardan and Andi will count the size of the garden, with the size of its long and wide is $2 \mathrm{~m}$, and has $24 \mathrm{~m} 2$ size. Ardan think the long and wide of that garden is $4 \mathrm{~m}$ and $2 \mathrm{~m}$, And think it is $4 \mathrm{~m}$ and $6 \mathrm{~m}$. which is right? And explain why he is right!

\section{RESULTS AND DISCUSSION}

\section{Result}

Figure According to the research, the result of the data from pre-test and post-test then formulated using SPSS software v.22 to know the result of pretest, posttest and n-gain as showed in the table below : Normalize pretest and Math solving problem skill

Tabel 1 Normalize pretest and Math solving problem skill result

\begin{tabular}{lrll}
\hline & & Eksperiment & Control \\
\hline pretes & $\overline{\mathrm{x}}$ & 3.87 & 3.00 \\
& SD & 2.306 & 1.844 \\
& Sig. & .188 & .200 \\
postes & $\overline{\mathrm{x}}$ & 12.61 & 6.90 \\
& SD & 3.138 & 3.187 \\
& Sig. & .200 & .200 \\
$\mathrm{~N}-$ & $\overline{\mathrm{x}}$ & .529 & .219 \\
Gain & SD & .212 & .209 \\
& Sig. & .000 & .000 \\
\hline
\end{tabular}


84 Fadhillah., Mahmudah, \& Kuriawan. Improving The Ability of Problem Solving and Independence of Mathematical Vocation School Through Contextual Approaches

As shown in table 1 showed that pre-test has significance value in Kolmogorov-smirnov show that experiment class .02 and control class .02 which mean the significant for both class is $\leq .05$ therefore $\mathrm{H}_{0}$ is rejected. This mean both of the sample come from not normal distribution. The post-test significant result in Kolmogorov-smirnov showed that for experiment class .200 and for control class .200 which mean experiment class $.200 \mathrm{H}_{0}$ accepted and control class, $\mathrm{H}_{0}$ accepted.

This mean both of the sample come from normal population. This mean both of data distributed normally for $\mathrm{N}$-gin so the significance value of Kolmogorov-smirnov showed that experiment class .20 and control class .20 which means both of the class $\geq .05$ threfore $\mathrm{H}_{0}$ is accepted. This mean both of the sample come from normal population. This mean both of data distributed normally for $\mathrm{N}$-gin so the significance value of Kolmogorov-smirnov showed that experiment class .20 and control class .20 which means both of the class $\geq .05$ threfore $\mathrm{H}_{0}$ is accepted.

This mean both of the sample come from normal population. This mean both of data distributed normally for $\mathrm{N}$-gin so the significance value of Kolmogorov-smirnov showed that experiment class .20 and control class .20 which means both of the class $\geq .05$ threfore $\mathrm{H}_{0}$ is accepted.

Table 2. Average test analysis result

\begin{tabular}{llll}
\hline & $\operatorname{sig}(2$-tailed) & $\begin{array}{c}\text { Monte } \\
\text { Carlo sig. } \\
\text { (1-tailed) }\end{array}$ & $\begin{array}{c}\text { Monte } \\
\text { Carlo sig. } \\
\text { (1-tailed) }\end{array}$ \\
\hline Pretes & .106 & & \\
postes & & $.000^{\mathrm{b}}$ & \\
N-Gain & & & $.000^{\mathrm{b}}$ \\
\hline
\end{tabular}

Based on table 2 for pretest showd that .sig (2-tailed) is .106 has sig. $>.05$ therefore H0 Is accepted. This mean the difference of significane ability math problem solving between two class experiment and control class. Posttest monte carlo sig (1-tailed) test Mann-withney is .000. The signivicance value less than .05 therefore $\mathrm{H} 0$ is rejected. This mean the students increasing in contextual approach is better than conventional learning

\section{Discussion}

The research done by giving the different treatment between experiment class and control class using contextual approach, the treatment of control class and conventional one. The solving problem and math contextual approach is better than conventional one.

The description of the achievement and improvement of students' mathematical problem solving abilities in the experimental class and control class above shows that students who learn to use the contextual approach assisted by power point have more positive influence on the achievement and improvement of mathematical problem solving abilities compared to students who use the scientific approach only. This is because students in the experimental class whose learning uses the contextual approach assisted by power point are given more opportunities to form hypotheses and test hypotheses by verifying the results of their observations with data or theory in the source book, so that students become more active and creative in the learning process. This is in line with Hendriana \& Fadhillah (2019) opinion that in solving mathematical problems the learning process students must understand the 
problems contained in the worksheet and students must plan problem solving. Implementation using contextual approach:

1. In the learning using contextual approach at first the teacher giving motivation to the students (constructivism) to make the students motivated in learning and setting learning goal.

2. The teacher gives a slight learning material which give questions to students related to material given to students to make the students understand on how to use learning material in daily life (question-answer)

3. After giving a slight learning material and asking to the student, then student need to share their experience in daily life related to learning material given as the example of the correlated between learning material and daily life (modelling).

4. To make contextual approach this could increase the solving problem skill which is not only the correlation between the material and daily life, teacher make group of students consist of 4 people (Learning society).

5. In Learning society every group given worksheet to solve the math problem, teacher guide and monitor what have been done by the students.

6. Worksheet done by each group then presented (reflection). At first every group presented what have they done but the next meeting every group compete to present their task.

7. The first group presenting their work, teacher give them point (authentic assessment) so every group motivated.

In learning using contextual approach, in the end of the test to measure the solving problem ability. With passing level criteria minimum $70 \%$.

1) First test indicator of problem solving tested is, the plan of solving question number 1 showed $80.25 \%$. This showed that most of students in the experiment class able to answer number 1 pretty well.

2) Second indicator solving problem tested is, solving problem. Question number show the percentage of $88.25 \%$. This showed that experiment control class able to answer question number 2 well.

3) Second indicator solving problem tested is, solving problem. Question number show the percentage of $85.5 \%$. This showed that experiment control class able to answer question number 3 well.

4) Second indicator solving problem tested is, solving problem. Question number show the percentage of $69.5 \%$. This showed that experiment control class able to answer question number 4 well.

5) Second indicator solving problem tested is, solving problem. Question number show the percentage of $84.5 \%$. This showed that experiment control class able to answer question number 5 well.

The difficulties students have can be seen in the picture below

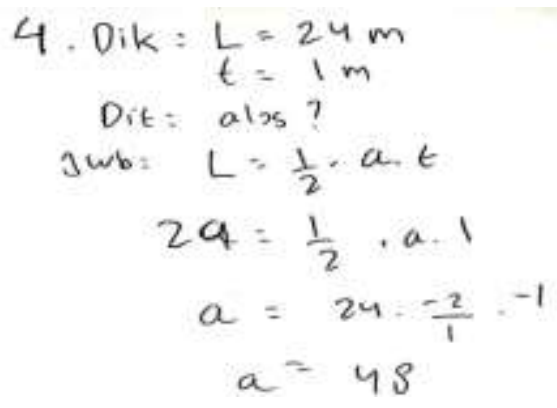

Figure 1. Answers of Students with Difficulties in Solving Questions 
86 Fadhillah., Mahmudah, \& Kuriawan. Improving The Ability of Problem Solving and Independence of Mathematical Vocation School Through Contextual Approaches

This is one of the results of students in working on math problems. Students have difficulty in solving math problems as shown above.

\section{CONCLUSION}

The achievement of math solving problem using contextual approach is better than conventional one. The experiment class having difficulties in answering question number 4 (solving planning) mostly control class having difficulties in answering question number 5 (Understanding the question).

\section{ACKNOWLEDGMENTS}

Based on research result and the conclusion about the learning using contextual approach can be concluded as: Contextual approach should be used for alternative learning because it could increase solving problem skill and student math independent learning, Applying contextual approach should be start with well planning so in the learning process we could get what we hope as well as the effective of time usage. Learning with contextual approach could create active learning situation, find a material concept which learned and stated ideas in their own words, make an argumentation.

\section{REFERENCES}

Hajar, Y., \& Sari, V. T. A. (2018). Analisis Kemampuan Pemecahan Masalah Siswa SMK Ditinjau dari Disposisi Matematis. Jurnal Inovasi Pendidikan Dan Pembelajaran Matematika, 4(2), 120-131.

Haji, S., \& Abdullah, M. I. (2015). Membangun Kemandirian Belajar Siswa melalui Pembelajaran Matematika Realistik. Infinity Journal, 4(1), 39-46.

Hendriana, H., \& Fadhillah, F. M. (2019). The Students' Mathematical Creative Thinking Ability of Junior High School Through Problem-Solving Approach. Infinity Journal, $8(1), 11-18$.

Krismiati, A. (2013). Penerapan Pembelajaran dengan Pendidikan Matematika Realistik (PMR) secara Berkelompok untuk Meningkatkan Kemampuan Pemecahan Masalah Matematis Siswa di Kelas X SMA. Infinity Journal, 2(2), 123-135.

Marlissa, I., \& Widjajanti, D. B. (2015). Pengaruh Strategi React Ditinjau dari Gaya Kognitif terhadap Kemampuan Pemecahan Masalah, Prestasi Belajar dan Apresiasi Siswa terhadap Matematika. Jurnal Riset Pendidikan Matematika, 2(2), 186-196. Retrieved from http://journal.uny.ac.id/index.php/jrpm/index

Putri, R. M., \& Eliarti, W. (2017). Perbandingan Model Pembelajaran CORE dengan Discovery Learning dalam Pembelajaran Matematika terhadap Kemampuan Pemecahan Masalah Matematis dan Self-Regulated Learning Siswa SMA. Pasundan Journal of Research in Mathematics Learning and Education, 2(2), 129-138.

Ruseffendi, E. T. (2010). Dasar - Dasar Penelitian Pendidkan dan Bidang Non-Eksakta Lainnya. Bandung: Tarsito.

Sariningsih, R. (2014). Pendekatan Kontekstual untuk Meningkatkan Kemampuan Pemahaman Matematis Siswa SMP. Infinity Journal, 3(2), 150-163. 
Sariningsih, R., \& Purwasih, R. (2017). Pembelajaran Problem Based Learning untuk Meningkatkan Kemampuan Pemecahan Masalah Matematis dan Self Efficacy Mahasiswa Calon Guru. Jurnal Nasional Pendidikan Matematika, 1(1), 163-177.

Sugandi, A. I. (2013). Pengaruh Pembelajaran Berbasis Masalah dengan Setting Kooperatif Jigsaw terhadap Kemandirian Belajar Siswa SMA. Infinity Journal, 2(2), 144-155.

Wirdaningsih, S., Arnawa, I. M., \& Anhar, A. (2015). Pengembangan Perangkat Pembelajaran dengan Pendekatan Contextual Teaching and Learning untuk Meningkatkan Kemampuan Pemecahan Masalah Peserta Didik Kelas XI. Jurnal Nasional Pendidikan Matematika, 1(2), 275-289. 